\title{
NIHON-SEI : COMPUTER-AIDED INSTRUCTION THAT TEACHES BASIC JAPANESE
}

\author{
Daryl L. Montalbo \\ University of the East-Manila \\ Lot 6 Blk 2 Azicate Homes Valenzuela City \\ montalbo.daryl@yahoo.com \\ Rhea R. Regis \\ University of the East-Manila \\ 1342 Villacampo Bagbaguin Caloocan City \\ rhearegis20@gmail.com \\ Crystal Gail S. Quijano \\ University of the East-Manila \\ 505 apple ville sta quiteria caloocan city \\ crystalquijano217@gmail.com \\ Melie Jim F. Sarmiento \\ University of the East-Manila \\ 8 Avocado St. TCEV Antipolo City \\ mjfsarmiento@yahoo.com
}

\begin{abstract}
This study examines which media incorporated in a developed Computer-Aided Instruction (CAI) will be useful for the students taking up Nihongo classes. The CAI program was developed using a tutorial mode of presentation covering basic greetings, sentence patterns, number systems and hiragana characters. Each of these topics will have the following media in the flash lectures: text only, text-graphics, text-graphics-sounds and text-graphics-animation-sounds. Students in class were divided into four groups: the first group used text only media; the second group used text-graphics; the third group used text, graphics and sound; and the last group used text, graphics, sounds and animation. Examination was administered at the end of every lesson. ANOVA was used to determine the significant difference in the performance of students using different types of media. From the four media types of Flash lessons embedded in the system, the most effective media were text with graphics, sounds, and animation. Animations with the right text, graphics and sounds are a
\end{abstract}


useful aid in making lessons meaningful for students.

Keywords: Animation, Computer-Aided Instruction, Graphics, Nihongo, Sounds, Text, Multimedia

\section{LANGUAGE TOWARDS TECHNOLOGY}

The ability to communicate effectively through language is necessary for understanding. Without communication, there is no way to express thoughts, ideas, or feelings. Modern technologies have played a huge role in making communication easier. According to Galembeck ${ }^{1}$, students are more motivated and can learn better when they are actively engaged than when they are simply watching and listening. Having readers participate more actively in the comprehension process can aid in memory learning, according to Gasparinatou ${ }^{2}$. Text with a design or presented with animation can be easily remembered by students. Nowadays, teachers use technology to increase the interest of their students in the subject matter.

\section{REVIEW OF RELATED LITERATURE AND STUDIES}

Torres $^{3}$ noted that students have become bored with conventional teaching methods such as writing the lessons on the blackboard. The main advantage of modern method is the centered classroom instruction which is created by the teacher and accepted by the students. According to Allen ${ }^{4}, 13$ years of educational research supports the generalization that instruction can be significantly improved through the wise selection and use of sound, motion picture, film, filmstrips, educational television and the interrelated use of appropriate slides, transparencies, models, specimens, and charts. $\mathrm{He}$ also concluded that 50 years of instructional media research in the United States has focused the attention of educators and the public on instructional media as a legitimate and viable channel for the transmission of educational content. Research has confirmed media effectiveness, supplied a base of suppositions and hypothesis regarding the unique attribute of instructional media which can be studied under controlled experimental conditions, and released the richness and diversity of the utilization of media.

\section{DATA AND METHODOLOGY}

The present study used the data mining method. The software was produced from July to August 2012. The number of students in a group was determined by the number of students in the class. The study was conducted 
at the University of the East Manila, first semester of S.Y. 2011-2012 from August to September. The implementation process was held in CS302. The system was used 8 to 10 times, twice a week on Monday and Friday. The respondents were students who are currently taking Nihongo. The software was composed of lectures and examinations for every topic.

\section{SUMMARY OF FINDINGS}

Examinations on different topics were conducted. The activity was aimed at unveiling rate of effectiveness of media, namely text only, text and graphics only, text, graphics and sounds, or text, graphics, sounds, and animation.

Table 1. Students average score

\begin{tabular}{ccccc}
\hline & $\begin{array}{c}\text { Text } \\
\text { only }\end{array}$ & $\begin{array}{c}\text { Text and } \\
\text { Graphics only }\end{array}$ & $\begin{array}{c}\text { Text, Graphics and } \\
\text { Sounds only }\end{array}$ & $\begin{array}{c}\text { Text, Graphics, Sounds } \\
\text { and Animations }\end{array}$ \\
\hline Basic & & & & 46.25 \\
Greetings & 30.5 & 23.25 & 31 & \\
Sentence & & & & 46.25 \\
Pattern & 30.5 & 38.75 & 37 & 45.25 \\
Numbers & 23.75 & 41.5 & 41.75 & 44.5 \\
Hirgana & 41.5 & 41.75 & & \\
\hline
\end{tabular}

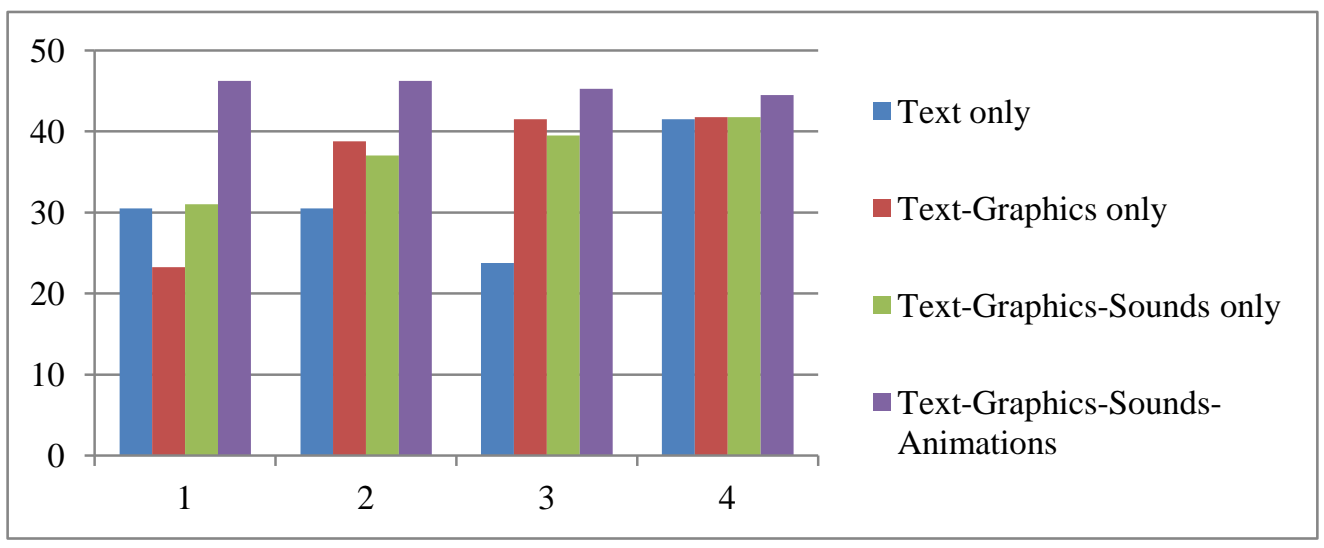

Figure 1. Students average score

Table 1 and Figure 1 show the performance of the students in the examination given to them. From the four media types of Flash lessons embedded in the system, the most effective media was a combination of text, graphics, sounds, and animation. 


\section{CONCLUSION}

Computer-aided instruction is a useful and effective learning aid in teaching Nihongo to undergraduate students. It is a powerful, useful and interesting mode of instruction for teachers and learners. The tutorial form of this program was found to be applicable in helping teachers and students on their journey in learning a new language. This study demonstrated that with the incorporation of a properly designed multimedia in CAI, understanding of the students will be enhanced far more than through traditional teaching methods.

\section{RECOMMENDATION}

The researchers recommend that CAI program be utilized in creating tutorials that can enhanced the quality of education for subjects other than Nihongo. The researchers recommend the developed software to all undergraduate students, professionals, and others who want to learn basic Nihongo. The same study should be replicated by future researchers to enhance the system and provide more media, so that students can choose the kind of media that they want to use. The researchers also recommend adding other topics in nihongo that will give more information to the students. It is a challenge for the next researchers to continue developing such a system for teaching, not only Nihongo, but other fields of studies as well.

\section{REFERENCES}

[1] E. Galembeck, G.A. Marson, and B.B. Torres, Different energy sources in sports: Introductory software. Biochemistry and Molecular Biology Education, 31(3), p204-208, 2003. http://dx.doi.org/10.1002/bmb.2003.494031030208.

[2] A. Gasparinatou, Effects of background knowledge and text coherence on learning from text in informatics. Retrieved on January 12, 2011 from

http://webcache.googleusercontent.com/search?q=cache:kewEp3SgIg8 J:www.researchgate.net/publication/226255486_Enhancing_Learning_ from_Informatics_Texts/file/d912f51220e231a115.pdf+\&cd=1\&hl=en $\& \mathrm{ct}=\mathrm{clnk} \& \mathrm{gl}=\mathrm{ph}$.

[3] E. Galembec, G. Marson, and B. Torres. A quick guide for computerassisted instruction in computational biology and bioinformatics. Retrieved on January 10, 2011 from http://www.ploscompbiol.org/article/info\%3Adoi\%2F10.1371\%2Fjour nal.pcbi. $1000035 \mathrm{~W}$. 
Daryl L. Montalbo, Rhea R. Regis, Crystal Gail S. Quijano, and Melie Jim F. 107

[4] Allen, Instructional media research from past, present and future. Audio communication review, 19(1), p1-10, 1997. 
